\title{
The effects of tillage methods on soil aggregation and crop yields in a
} wheat-corn rotation under semi-arid conditions

\author{
Hossein Tabiehzad ${ }^{1}$, Gokhan Cayci $^{2}$, Kiarash Afshar Pour Rezaeieh ${ }^{3 *}$ \\ ${ }^{1}$ Department of soil and water, Agricultural Research Center of West Azerbaijan, Urmia, \\ Iran \\ ${ }^{2}$ Department of Soil Science and Plant Nutrition, Faculty of Agriculture, Ankara University, \\ Ankara, Turkey \\ ${ }^{3}$ Department of Field Crops, Agricultural Faculty, Igdir University, Igdir, Turkey \\ Corresponding author: febspark7@gmail.com
}

\begin{abstract}
In this study, the effects of different tillage methods under wheat-corn two-course rotation system on the some soil aggregation properties and yields were investigated. Experiment was laid out in a split plot design with three replications during four crop years. Subsoiler, moldboard, sweep and chisel as main plots and rotary tiller and disc harrow as sub-plots have been used in this study. The results showed that tillage methods were significant at $(\mathrm{P}<0.01)$ as regards crop yields, and the highest yields as 6249 and $11720 \mathrm{~kg} / \mathrm{ha}$ for wheat and 9891 and $73080 \mathrm{~kg} / \mathrm{ha}$ for corn grain and biomass were produced in subsoiler treatment, respectively. Subsoiler+rotarytiller treatment was significant at $(\mathrm{P}<0.05)$ with $2.063 \mathrm{~mm}$ as to mean weight diameter (MWD) value. The subsoiler and chisel were statistically in the same group with regard of water stable aggregates (WSA) value, and it was significant at $(\mathrm{P}<0.05)$ with $67,83 \%$. Bulk density, total porosity and air porosity values were significant at $(\mathrm{P}<0.01)$, and $1.38 \mathrm{grcm}^{-3}, 51.2 \%$ and $12.5 \%$ values were determined in rotary tiller application, respectively. Field capacity (FC) and permanent wilting point (PWP) were significant at $(\mathrm{P}<0.05)$ and $(\mathrm{P}<0.01)$ with $31.89 \%$ and $17.21 \%$ values in the chisel treatment, respectively. Crop yields and positive effects on the physical properties were considered subsoiler+rotary tiller treatment was the most successful, and it was followed by chisel+rotary tiller treatment according to four-year study results.
\end{abstract}

Key words: Soil quality, subsoiler, chiesel, soil structure 


\section{Introduction}

The soil as a natural resource for the future of mankind must necessarily be managed in a sustainable manner. Thus, to preserve agriculture for future generations, developing production systems that conserve and enhance soil quality is fundamental (Doran and Zeiss, 2000). The retention of water and soil conservation are important in arid and semi-arid regions. Additionally, maintaining of organic matter is so difficult because of high temperature at these regions (Laegried et al. 1999). Gumus and Seker (2015) have pointed to the importance of organic matter in sustainable soil productivity in semi-arid areas where organic matter is low. It is well known organic carbon is more accumulated in the surface part of the soil. Sufficient level of organic matter in the top soil improves the physical, chemical, and biological features and thereby qualities of soils (Sojka and Upchurch 1999). On the other hand, studies on soil tillage show that the most accumulation of organic matter has been found in direct sowing, minimum and conventional tillage methods, respectively (Anonymous 2002).

The amount of organic matter in soil and soil aggregate stability is low in arid and semi-arid regions. Due to irregularities in rainfall with regard to time and intensity in arid and semiarid regions, soil erosion and soil loss increases and aggregate stability decreases. Moreover, excessive or incorrect tillage reduce the soil characteristics and quality (Chenu et al. 2000; Marinari et al. 2000). Alakkuku et al. (2003) reported that subsoil compaction due to increase of field traffic is a serious problem, because the effects are long-lasting and difficult to correct.

Tillage systems are basically evaluated in two categories: conventional tillage systems and conservational tillage systems. Conservational tillage covers the methods such as; minimum tillage, zero tillage, mulch tillage, ridge tillage and line tillage (Holland, 2004). It is mentioned that conservational tillage can reduce the yield in first years of implementation but it offers more protection against soil degradation and more improvement in quality of soil in long term (Lampurlanes et al. 2001). Primary tillage implements such as moldboard, turning the soil upside down, and excessive tillage practices are matter of concern in conventional tillage. Plant residues decompose in this method very quickly. Besides, it also leads to soil erosion and degradation and considerable amount of soil carbon exhaust in the form of carbon dioxide gas (Glanz 1995). 
Conservational tillage does not cover the moldboard methods but consists minimum tillage, direct sowing, and zero tillage as limited tillage. 15 up to 30 percent of plant residues remain on the surface part of the soil at this system and therefore, cultivator or herbicide is used to control the weeds (Gajri et al. 2002).

Tillage is one of the most important components of crop production that farmers have used to it more on the basis of their experiences. Publications related to cultivation and tillage, has been focused more on product yield than of changes appear in soil properties through the various tillage methods. Tillage practices today affects soil fertility and environmental quality. It will impact some restrictive soil properties, improve its properties and increase in the crop yield if practices reasonably and consciously (Lal 1991). Tillage affects soil fertility in short term and quality of soil in long term (Gajri et al. 2002). In spite of Bhattacharya et al. (2006), who believed that the soil tillage methods, in addition to improve of physical properties and content of organic matter and soil characteristics, leads to changes in soil fertility, Melero et al. (2011) argued that the effects of soil tillage methods on physical properties varies and is not guaranteed. Similarly, Strudly et al. (2008) indicated soil tillage studies can display changes depending on the experimental designs and trial locations. Srivastava and Meyer (1998) reported that soil tillage systems could have advantages and disadvantages in different situations, but there is no an ideal single system in all soil, climate and crop conditions.

No-till farming practices are increasing in recent years, although, it is required to the preparation of the seed bed in arid and semi- arid regions of mechanical operations. Today, instead of excess tillage and conventional tillage methods, in some areas farmers have begun to use protected or reduced tillage methods. These methods are combined with reduced tillage practices using tools and equipment, and they are preferred especially for strategic products such as wheat and corn.

In Urmia $\left(37^{\circ} 33^{\prime} 19^{\prime \prime} \mathrm{N} 45^{\circ} 04^{\prime} 21^{\prime \prime} \mathrm{E}\right)$, located in the northern west Iran, farmers use conventional tillage methods as the first plow tillage and disk harrow as the second to prepare the soil. The common rotation systems in the region are as wheat-sunflower, wheatsugar beet and wheat-corn. The aim of this study was to determine the effects of tillage methods on wheat-corn double rotation system, soil aggregation characteristics and yield of wheat and corn as well. 


\section{Materials and Methods}

99

100

101

102

103

104

105

106

107

108

109

110

\subsection{Material}

\subsubsection{Trial Location}

The trial was conducted at Saaetloo Agricultural Research Station $\left(37^{\circ} 43^{\prime} 31^{\prime \prime} \mathrm{N}\right.$ and $45^{\circ}$ 01' 59 ") located 20 kilometers north of Urumia, Iran.

\subsubsection{Soil and climate characteristics of the experimental field}

Some soil properties of the experimental field and some climate characteristics are given in Table 1 and 2 . The field is flat with very low slope. Top soil texture $(0-60 \mathrm{~cm})$ is silty clay loam and getting heavier in the deeper depths as silty clay. According to Soil Survey Staff (2006), soil is classified as fine, mixed, super active, and it is mesic Typic Haploxerepts.

\subsubsection{The plants}

"Zerrin" wheat variety and Yugoslavia silage corn (SC704) were used as plant materials.

Table 1. Soil properties of the experimental field

\begin{tabular}{cccccccccccc}
\hline & & & & \multicolumn{1}{c}{ Organic } \\
Depth & Clay & Silt & Sand & Saturation & $\mathrm{N}$ & $\mathrm{P}$ & $\mathrm{K}$ & $\mathrm{carbon}$ & $\mathrm{CaCO}_{3}$ & $\mathrm{pH}$ & $\mathrm{EC}$ \\
$(\mathrm{cm})$ & $(\%)$ & $(\%)$ & $(\%)$ & $(\%)$ & $(\%)$ & $(\mathrm{ppm})$ & $(\mathrm{ppm})$ & $(\%)$ & $(\%)$ & $(\mathrm{dS} / \mathrm{m})$ \\
$0-30$ & 42 & 47 & 11 & 50 & 0.095 & 4.51 & 396 & 0,95 & 18 & 7.60 & 1.49
\end{tabular}

111

112 Table 2. Means of the maximum temperature $\left({ }^{\circ} \mathrm{C}\right)$ and average total precipitation $(\mathrm{mm})$ during 113

\begin{tabular}{|c|c|c|c|c|c|c|c|c|c|c|c|c|c|}
\hline Month & $\stackrel{\overparen{\Xi}}{\Xi}$ & 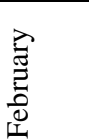 & $\begin{array}{l}\text { D̃ } \\
\stackrel{\Xi}{\Sigma}\end{array}$ & $\overline{\overline{0}}$ & $\stackrel{\vec{J}}{\grave{I}}$ & $\stackrel{\Xi}{\Xi}$ & $\stackrel{\lambda}{\Xi}$ & 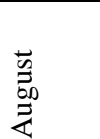 & 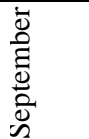 & 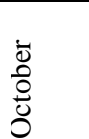 & $\begin{array}{l}\dot{\bar{D}} \\
\text { है } \\
\text { Dे } \\
\text { Z }\end{array}$ & 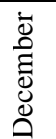 & 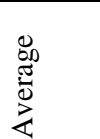 \\
\hline $\begin{array}{c}\text { Temperature } \\
\left({ }^{\circ} \mathrm{C}\right)\end{array}$ & -6.43 & -4.45 & -1.78 & 3.21 & 7.37 & 110 & 5.22 & 15.64 & 11.8 & 7.45 & 2.71 & 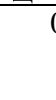 & 5.19 \\
\hline $\begin{array}{c}\text { Precipitation } \\
\text { (mm) }\end{array}$ & 19.9 & 30.6 & 39.6 & 48.9 & $39 ., 7$ & 11.8 & 4.42 & 3.49 & 6.76 & 29.7 & 45.8 & ( & 297.8 \\
\hline
\end{tabular}

114

\subsection{Method}

\subsubsection{Treatments}

117 The experiment was carried out in a split-plot block design with three replications. Four

118 tillage implementations were as the main plots and the other two tillage methods as the sub

119 plots under wheat-corn rotation system. This rotation system is one of the most preferred system of farmers in the region. Wheat cultivated at the range of 160-180 kg/ha. After the wheat harvest, all tillage methods were applied to the plots and silage corn was planted in 

phosphate were applied to the wheat in 2009-2010, 2010-2011, 2011-2012 and 2012-2013 growing seasons, respectively. On the other hand, 350, 320 and $300 \mathrm{~kg} / \mathrm{ha}$ urea and 150 ,

125160 and $175 \mathrm{~kg} / \mathrm{ha}$ triple super phosphate were applied to the corn in 2010-2011, 2011-

1262012 and 2012-2013 growing seasons, respectively.

\subsubsection{Soil analyses}

128 Soil samples were taken from the depth of $0-15 \mathrm{~cm}$ after the wheat harvest in 2013. Eight samples were taken from each plot and mixed each other and the soil sample obtained from

130 this mixture was used for analysis. Soil texture was determined by hydrometer method 131 described by Bouyoucos (1951), textural classes were determined using the texture triangle specified by Soil Survey Division Staff (1993). Saturating the soil samples with water, soil acidity of the soil-water extract $1 / 2.5(\mathrm{w} / \mathrm{w})$ by the $\mathrm{pH}$ meter, the electrical conductivity of

134 the saturation extract from a soil-water paste by EC meter and bulk density at undisturbed soil samples were determined according to U.S. Salinity Laboratory Staff (1954). The moisture contents of undisturbed samples at field capacity and wilting point were determined using pressure plate (Cassel and Nielsen 1986). Macro and micro pore amounts in undisturbed samples were measured using by porous ceramic plates creating a negative pressure of $50 \mathrm{~cm}$ (Romano et al. 2002). Saturated hydraulic conductivity of undisturbed samples was measured using constant head permeameter (Klute and Dirksen 1986). weight diameter was calculated as indicated by Hillel (1980) the diameter size distribution considering the dry aggregates. Organic carbon was measured as indicated by Nelson

144 (1982). Calcium carbonate content was determined by calsimeter method according to 145 Nelson (1982). Total nitrogen was analyzed as reported by Bremner (1982) applying the 146 micro-kjeldahl method. Available phosphorus was determined as indicated Olsen et al.

147 (1954). Available potassium was measured as noted by Jackson (1958).

\section{$148 \quad$ 2.2.3 Statistical analysis}

149 Statistical analysis was performed using MSTAT-C program.

150 3. Results and Discussion

\section{$151 \quad 3.1$ Grain and biomass yield of wheat and corn}

152 Significant effects of tillage methods on grain and biomass of yield of wheat and corn and 153 aggregation properties of the soil were determined. Treatments on wheat grain yield and 
154 biomass production has been identified distinct and the four year application results of the 155 variance analysis of the main-plots and sub-plots was found to be significant at the $(\mathrm{p}<0.01)$ 156 level (Table 3). The highest wheat grain and biomass yield $(6249 \mathrm{~kg} / \mathrm{ha}$ and $11720 \mathrm{~kg} / \mathrm{ha}$, 157 respectively) was identified in subsoiler application, while the lowest amounts in the same 158 order was determined as $4777 \mathrm{~kg} / \mathrm{ha}$ and $9770 \mathrm{~kg} / \mathrm{ha}$ in the mouldboard plough practice.

159 According to the results of three-year variance analysis, corn grain and biomass yield 160 productions at the sub-plots and main plots were significant at the $(\mathrm{p}<0.01)$ level. Maximum 161 corn grain yield and biomass production were recorded $(9891 \mathrm{~kg} / \mathrm{ha}$ and $73080 \mathrm{~kg} / \mathrm{ha}$, 162 respectively) subsoiler treatment, while the lowest amounts in the same order were again 163 determined as $8176 \mathrm{~kg} / \mathrm{ha}$ and $57350 \mathrm{~kg} / \mathrm{ha}$ in the mouldboard plough practice. (Table 3).

164 Subsoiler has been identified more effective than the other tillage methods both wheat and corn. Deep tillage practices in semi-arid regions of India has been proved to be effective in corn and sunflower cultivation by Arora (1991) and Gajri et al. (1997). In current study, chisel practice took the second place in increasing both grain and biomass production of wheat. In corn growing, subsoiler and chisel practices were in the same group, statistically.

Table 3. Effect of tillage methods on wheat and corn grain-biomass yield $(\mathrm{kg} / \mathrm{ha})$

Tillage Methods Wheat biomass Wheat grain Corn biomass Corn grain

\begin{tabular}{lcccccccc}
\hline Subsoiler & 11720 & $\mathbf{a}$ & 6249 & $\mathbf{a}$ & 73080 & $\mathbf{a}$ & 9891 & $\mathbf{a}$ \\
Sweep & 10400 & $\mathbf{b}$ & 5593 & $\mathbf{b}$ & 69370 & $\mathbf{a}$ & 9023 & $\mathbf{a b}$ \\
Moldboard & 10330 & $\mathbf{b c}$ & 5045 & $\mathbf{c}$ & 57010 & $\mathbf{b}$ & 8853 & $\mathbf{b}$ \\
Chisel & 9770 & $\mathbf{c}$ & 4777 & $\mathbf{c}$ & 57350 & $\mathbf{b}$ & 8176 & $\mathbf{b}$ \\
Probability P<0.01 & LSD: 599,7 & & LSD: 379,3 & LSD: 6178 & LSD: 970 & \\
\hline Tillage Methods & \multicolumn{2}{l}{ Wheat biomass } & Wheat grain & Corn biomass & \multicolumn{2}{c}{ Corn grain }
\end{tabular}

\begin{tabular}{lcccccccc}
\hline Rotary tiller & 10794 & $\mathbf{a}$ & 5601 & $\mathbf{a}$ & 68882 & $\mathbf{a}$ & 9442 & $\mathbf{a}$ \\
Disc harrow & 10317 & $\mathbf{b}$ & 5230 & $\mathbf{b}$ & 59525 & $\mathbf{b}$ & 8528 & $\mathbf{b}$ \\
Probability \% & $\mathrm{P}<0.01$ & & $\mathrm{P}<0.01$ & & $\mathrm{P}<0.01$ & & $\mathrm{P}<0.01$ & \\
\hline
\end{tabular}

171

Statistically significant difference between the means is shown in separate letters 
173 These data are consistent with results of previous studies including Diaz- Zorita and Grasso,

174 2000). According to Oussibl and Crookston (1987), deep subsoiler practice resulted in a $17554 \%$ yield increase by providing better wheat root growth and crop development, and it 176 causes a decrease in bulk density. Hajabbasi and Hemmat (2000) determined 7264 and 6815 $177 \mathrm{~kg} / \mathrm{ha}$ wheat grain yields under conventional and non-inversion tillage systems, respectively 178 as the four-year yield average. De vita et al. (2007) pointed to the amount of rainfall in 179 wheat yield and found that the no- tillage system should be preferred on continuous durum 180 wheat growing areas with a lower rainfall of $300 \mathrm{~mm}$, whereas more rainy areas 181 conventional tillage increased the wheat yields. Su et al. (2007) reported the winter wheat 182 yields were higher on no-tillage with mulching and subsoil tillage with mulching treatments 183 compared with conventional tillage, and proposed no-tillage and subsoil tillage systems 184 were the optimum tillage systems to increase yield, water storage and water use efficiency. 185 Root length density of corn was found to be effected by soil tillage systems, and the order 186 was moaldboard plow>chisel plow>no-till in the upper layers of soil (Mosaddaghi et al. 187 2008). On the other hand, Godwin (1990) stated that every year application of subsoiler is 188 not appropriate because it is an expensive process, but farmers may consider subsoiler 189 tillage method to tillage rotation when needed.

190 In rotary tiller, wheat grain and biomass yields of the sub-plots were $5601 \mathrm{~kg} / \mathrm{ha}$ and 10794 $191 \mathrm{~kg} / \mathrm{ha}$, respectively (Table 3). Compared to disc harrows, rotary tiller implementation resulted in an increase of $417 \mathrm{~kg} / \mathrm{ha}$ and $371 \mathrm{~kg} / \mathrm{ha}$ wheat grain and biomass, respectively. In addition, rotary tiller method led to a production of $9442 \mathrm{~kg} / \mathrm{ha}$ grain and $68882 \mathrm{~kg} / \mathrm{ha}$ biomass in corn. Compared to disc harrow, rotary tiller produced more corn grain and biomass of $1114 \mathrm{~kg} / \mathrm{ha}$ and $9357 \mathrm{~kg} / \mathrm{ha}$, respectively (Table 3). The outputs from current study confirms previous findings (Ozpınar and Cay 2005).

\subsection{Mean weight diameter of aggregates and hydraulic conductivity}

199 Mean weight diameter (MWD) results are given in Figures 1 and 2. Compared to other soil

200 tillage methods, MWD in the main plots was higher with $1.907 \mathrm{~mm}$ in subsoiler tillage

201 application (Figure 1). Considering main and sub plot interaction, subsoiler + rotary tiller

202 resulted in $2.063 \mathrm{~mm} \mathrm{MWD}$, while the lowest value was devoted to chisel + disc harrow

203 method (Figure 2). Bybordi (1990) stated that high MWD value implies high soil aggregate

204 stability. Follette (2001) mentioned that tillage methods have significant effect on MWD. 
Solid Earth Discuss., doi:10.5194/se-2017-13, 2017

Manuscript under review for journal Solid Earth

Discussion started: 1 March 2017

(c) Author(s) 2017. CC-BY 3.0 License.

Jaiyeoba (2003) reported a decrease of the stability of the aggregates because of conventional tillage practices. Filho et al. (2002) determined lower MWD in conventional tillage rather than zero tillage.

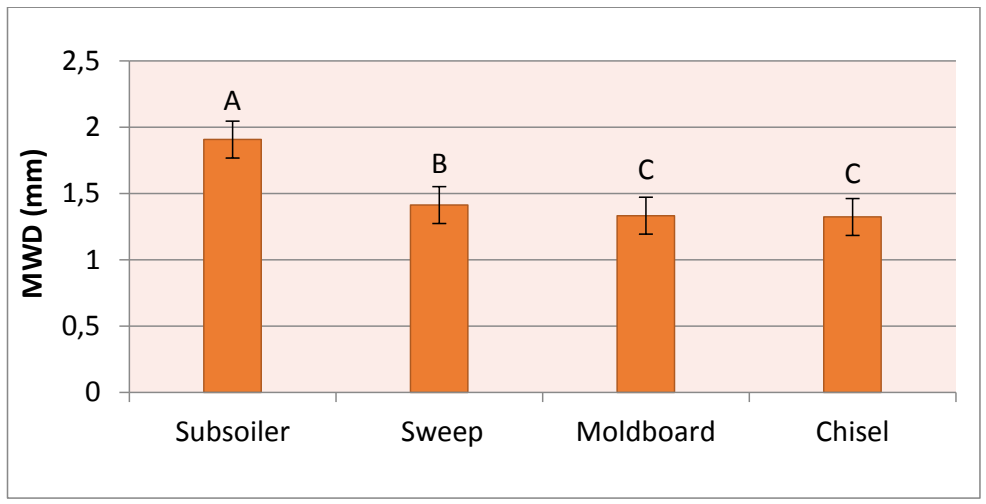

Figure 1. Effect of tillage methods on the mean weight diameter $(\mathrm{mm})$

The difference between the averages shown in separate letters $(\mathrm{P}<0.01)$

The error bars show SE values.

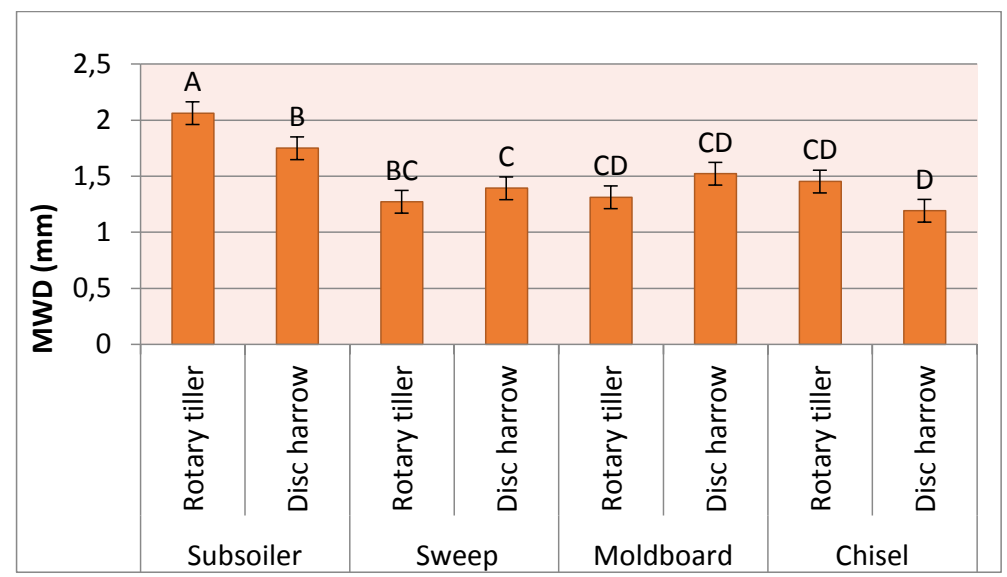

Figure 2. Effects of tillage methods on the mean weight diameter ( $\mathrm{mm})$.

The difference between the averages shown in separate letters $(\mathrm{P}<0.05)$

The error bars show SE values.

Hydraulic conductivity is closely related to water movement in the soil and tillage practices can influence on this feature. Variance analysis of tillage methods on hydraulic conductivity is given in Table 4. 
Table 4. Effect of tillage methods on hydraulic conductivity $(\mathrm{cm} / \mathrm{h})$

\begin{tabular}{|c|c|c|c|c|c|c|c|c|c|}
\hline Tillage Method & Subsoi & & Sweep & & Moldboarc & & Chisel & & Sub plot means \\
\hline Rotary tiller & 1.57 & $\mathrm{a}$ & 0.32 & $\mathrm{c}$ & 0.26 & $\mathrm{c}$ & 0.91 & $\mathrm{bc}$ & $1.57 \mathrm{a}$ \\
\hline Disc harrow & 1.04 & $\mathrm{~b}$ & 0.29 & $\mathrm{c}$ & 0.23 & $\mathrm{c}$ & 0.52 & $\mathrm{c}$ & $1.04 \mathrm{~b}$ \\
\hline Main plots means & 1.305 & $\mathrm{a}$ & 0.30 & $\mathrm{c}$ & 0.245 & $\mathrm{c}$ & 0.715 & $\mathrm{~b}$ & \\
\hline
\end{tabular}

Statistically significant difference between the means is shown in separate letters.

Main plot: $\mathrm{P}<0.01$, Sub plot: $\mathrm{P}<0.05$, Main plot - sub-plot interaction: $\mathrm{P}<0.05$

Subsoiler treatment of $1.305 \mathrm{~cm} / \mathrm{h}$ was found to have more hydraulic conductivity than the moldboard plow measured as $0.245 \mathrm{~cm} / \mathrm{h}$. Subsoiler + rotary tiller treatment with $1.57 \mathrm{~cm} / \mathrm{h}$ showed the highest value. Kahlon et al. (2013) reported that tillage systems can change the number, shape, continuity and size distribution of pore network. According to Germann et al. (1984) in the soil profile, water distribution and infiltration of conventional tillage system is as twice as zero tillage. Ahuja et al. (1989) reported that large voids are responsible for the effective porosity in soil, so that hydraulic conductivity and infiltration amounts in soil are affected by soil tillage methods. On the other hand, Osunbitan et al. (2005) indicated that the disturbance of continuity of macro pores under the conventional tillage is the most important factor for saturated hydraulic conductivity in the soils. It was noted that disc harrow, even in low levels, can cause compaction in the fields where there were no plant residues and non-mulching materials (Davies et al. 1999; Ghuman and Sur 2001).

\subsection{Bulk density, air porosity and total porosity}

244 Effects of tillage methods on bulk density, porosity and total porosity are given in Table 5. Rotary tiller application has led to $1,304 \mathrm{gr} \mathrm{cm}^{-3}$ bulk density comparing mean values. While in disc harrow application bulk density was found to be $1.394 \mathrm{~g} \mathrm{~cm}^{-3}$.

247 Table 5. The effects of tillage methods on bulk density, air porosity and total porosity

\begin{tabular}{ccccccc}
\hline Tillage Method & \multicolumn{2}{c}{ Bulk density $\left(\mathrm{gr} \mathrm{cm}^{-3}\right)$} & \multicolumn{2}{c}{ Air porosity $(\%)$} & \multicolumn{2}{c}{ Total porosity (\%) } \\
\hline Rotary tiller & 1.304 & $\mathrm{a}$ & 12.05 & $\mathrm{a}$ & 51.26 & $\mathrm{a}$ \\
Disc harrow & 1.394 & $\mathrm{~b}$ & 10.60 & $\mathrm{~b}$ & 49.48 & $\mathrm{~b}$ \\
Probability \% & $\mathrm{P}<0.01$ & & $\mathrm{P}<0.05$ & $\mathrm{P}<0.01$ & \\
\hline \multicolumn{5}{l}{ Statistically significant difference between the means is shown in separate letters. }
\end{tabular}
Soil tillage was found to decrease bulk density and hydraulic conductivity of the soil (Meek et al., 1992). Ozpınar and Cay (2005) reported effects of moldboard plow, disc harrow and 

conventional tillage method.

263 The highest soil porosity with $\% 51,2$ was determined in rotary tiller application when the

264 averages of the tillage practices compared with each other. While the lowest amount was 265 identified in disc harrow with \%49,4 (Table 5). Godwin (1990) reported soil aeration is relevant to total pore amount and the percentage of macro pores, and identified air porosity of $10 \%$ and above enough for many crops. Same author noted that fragmentation of soil aggregates and breaking of the pore continuity leads to reduced air porosity by increasing the retention of soil water. Abu-hamdeh (2003) stated that increase in wheat yield by increasing of soil aeration in compacted soils. Shiptalo and Protze (1987) investigated the effects of tillage on soil morphology and porosity and found the amount of macro pores in Ap horizons of no- tillage is about half of that found in the conventional tillage. $\mathrm{Xu}$ and Mermoud (2001) have indicated that subsoiling tillage increases the amount of larger pores $(>50 \mu \mathrm{m}$ diameter) but reduces the amount of smaller pores $(<10 \mu \mathrm{m}$ diameter). Increments in larger pores in subsoiled soil resulted in increases in hydraulic conductivity and infiltration rate compared to no-tillage soil.

\subsection{Water stable aggregates}

278 Effects of soil tillage methods on water stable aggregates are shown in Figure 3. Subsoiler and chisel treatments were in the same statistical group when comparing mean values. The 
In the soil management, persistency and stability of soil aggregation is associated with the size of aggregates (Traore et al. 2000; Whalen and Chang 2002). Nyamangar et al. (1999) indicated that there is need to root secretions in the soil for aggregates to be increased. Martens (2000) reported increases of water stable aggregates as a result of corn crop residues, and suggested less soil inverting methods to increase soil aggregation. Shaver et al. (2002) noted that no till cropping in wheat-corn rotation returned more crop residue, decreased bulk density, increased porosity and improved soil aggregation compared to wheat-fallow. Bronik and Lal (2005) noticed the effectiveness of organic matter and decomposition degree on the stability of aggregates. On the other hand, Abiven et al (2008) determined the correlation between decomposition characters of crop residues and soil aggregates. Meanwhile Shaver et al. (2002) and McVay (2006) determined increase of macro aggregates and total porosity due to high aggregate stability which in turn causes in high infiltration and water use efficiency. Kasper et al. (2009) determined the amounts of water stable aggregates under conventional and reduced tillage treatments as 18,2\% and $18,9 \%$, respectively, whereas it was found as $37,6 \%$ at minimum tillage practice. Besides, authors noted conventional tillage interfere more natural soil properties than reduced and minimum tillage.

\subsection{Field capacity and wilting point}

307 The effect of the tillage methods on field capacity is given in Figure 4. Comparing field capacity and soil tillage methods with each other revealed chisel and subsoiler methods in 

capacity values were obtained from the sweep and moldboard applications. When compared

311 the amounts of water retained at field capacity subsoiler, chisel and moldboard treatments

312 were found in the same statistical group, while lower amount was determined in the sweep 313 plow.

315

316

317

318

319

320

321

322

323

324

325

326

327

328

329

330

331

332 333

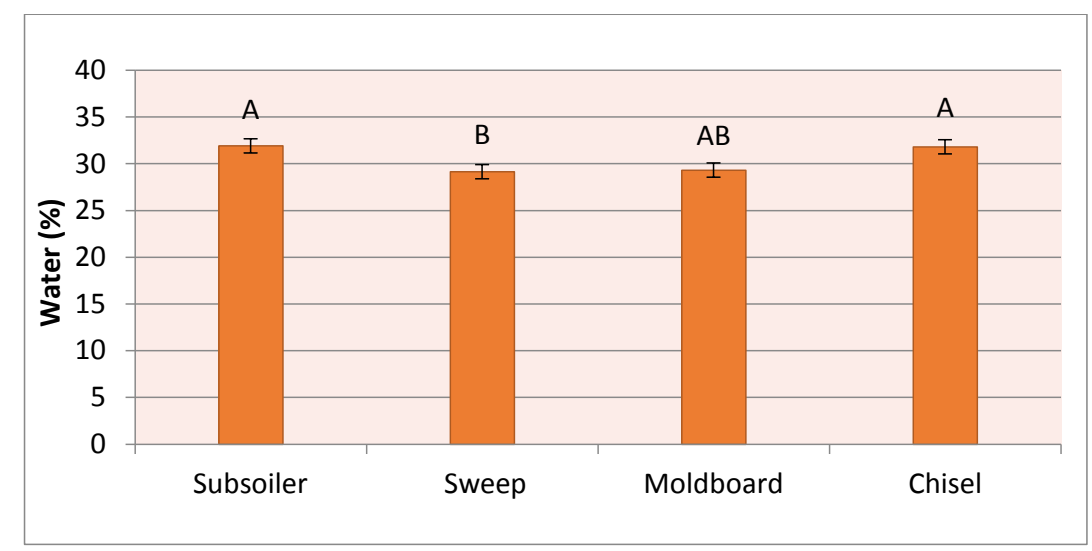

Figure 4. Effects of tillage methods on field capacity (\%)

Statistically significant difference between the means is shown in separate letters $(\mathrm{P}<0.05)$. The error bars show SE values.

Boone (1988) noted that tillage practices are effective on the amount of water both surface and below the soil. Accordingly, the changes due to the field traffic, affects the amount of porosity, number and continuity of the pores and the hydraulic properties of the soil. Logsdon et al. (1990) reported breaking of the continuity of pores in the soil in moldboard plow application, while the continuity was maintained in the ridge planting method. In a study carried out by Mahboubi et al. (1993), between soil tillage practices in terms of available water content, the order was zero tillage> chisel plow>moldboard plow. On the other hand, Vepraskas (1988) reported that the increase in bulk density causes an increase in penetration resistance and a decrease in the available water amount.

Effects of soil tillage methods on wilting point are shown in Figure 5. Comparing methods of tillage revealed chisel plow, moldbord plow and subsoiler plow in the same statistical group, while the highest moisture content $(17.21 \%)$ was determined at the wilting point in the chisel plow, and lowest value (15.78\%) was found in sweep plow (Figure 5). 


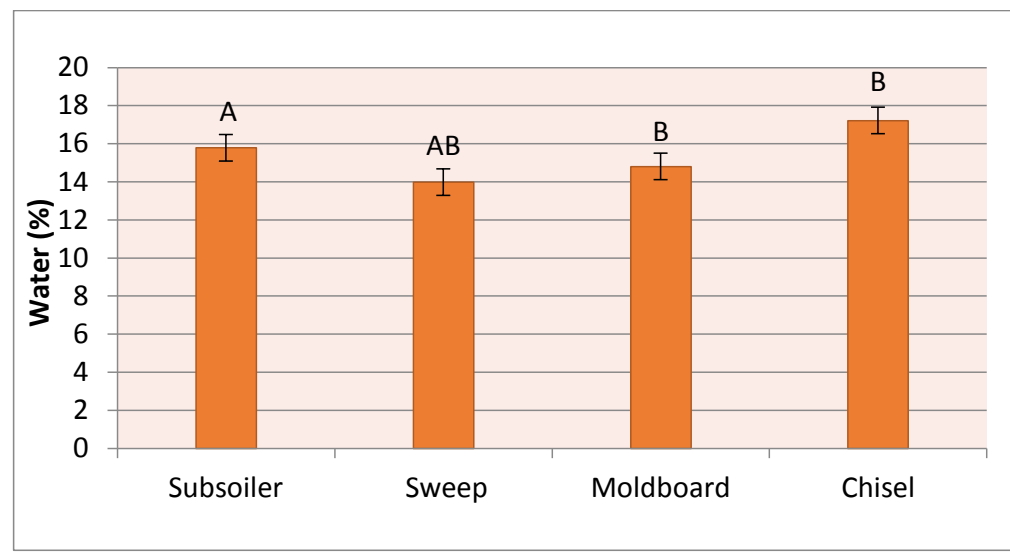

Figure 5. Effects of tillage methods on wilting point (\%)

Statistically significant difference between the means is shown in separate letters $(\mathrm{P}<0.05)$.

Bescanza et al. (2006) indicated the amount of available water in the tilled soils is related to the reorganization of pores and reported no-tillage and reduced tillage had higher soil water contents than the moldboard plowing at matric potentials of 0 to $-1500 \mathrm{kPa}$ according to the driest year of the five-year study period. Su et al. (2007) investigated the combined effects of tillage and mulching on soil water. They determined the soil water storage quantity was 25 and $24 \mathrm{~mm}$ higher in the mulching treatments of no-tillage and subsoil tillage, respectively, than conventional tillage and reduced tillage treatments according to six-year study results. Mahboubi et al. (1993) reported that available water holding capacity was in the order of no-till >chisel plowing > moldboard plowing according to long-term tillage experiments.

\section{Conclusions}

Considering wheat and corn grain and biomass yield, the most appropriate tillage method was identified as subsoiler + rotary tiller followed by chisel + rotary tiller application.

In compact soils suffering from intensive agriculture practices, subsoiler application brough about formation of cavities by breaking the lower layers, loosening of the soil and increasing air, water and heat movements. Thus, the movement of water in the soil would be facilitated and plant root depth in terms of better physical conditions would be provided.

On the other hand, subsoiler accompanying rotary tiller application increases wheat and corn seeds contact with the soil, provides the proper seed bed preparation and improves soil aeration. The study showed that the yield and soil properties were superior to rotary tiller considering the disc harrow. According to the research results, subsoiler and chisel were in 

conductivity, the mean weight diameter, amount of water-stable aggregate and field capacity values were found in the subsoiler. On the other hand, the highest total porosity and air porosity values were determined in the rotary tiller application. As a result of this research, considering either wheat or corn grain or biomass yields along with studied soil properties, subsoiler was the most suitable tillage method accompanying rotary tiller. In terms of efficiency and positive impact on soil properties, chisel application after subsoiler has been found to be applicable and promising. Considering the high energy costs of the subsoiler application, in wheat - corn rotation system a subsoiler + rotary tiller for every three or four years is preferable. While in other years, chisel + rotary tiller application may be suggested as the result of this experiment for practitioners.

370

\section{References}

372

373

374

375

376

377

378

379

380

381

382

383

384

385

386

387

388

389

Abiven, S., Menasseri, S., Angers, D.A. and Leterme, P. 2008. A model to predict soil aggregate stability dynamics following organic residue incorporation under field conditions. Soil Sci.Soc., Am. J., 72; 119-125.

Abu-Hamdeh, N.H. 2003. Effect of compaction and deep tillage on soil hydraulic aeration properties and wheat yield. Communication in Soil Science and Plant Analysis, 34; 2277-2290.

Ahuja, L.R., Cassel, D.K., Bruce, R.R. and Barnes, B.B. 1989. Evaluation of spatial distribution hydraulic conductivity using effective porosity data. Soil Sci., 148; 404-411.

Alakukku, L., Weisskopf, P., Chamen, W.C.T., Tijink, F.G.J., van der Linden, J.P., Pires, S., Sommer, C. and Spoor, G. 2003. Prevention strategies for field traffic-induced subsoil compaction: a review Part 1. Machine/soil interactions. Soil and Tillage Research, 73 (1-2); 145-160.

Anonymous. 2002. FAO, 2002.Website. http//www.fao.org.

Anonymous. 2011. Iran West Azerbaijan Meteorological Service.

Arora, V.K., Gajri, P.R. and Prihar, S.S. 1991. Tillage effects on corn in sandy soils in relation to water retentivity, nutrient and water management and seasonal evaporativity. Soil and Tillage Research, 21; 1-21. 
Baldev Sing, S. and Malhi, S. 2006. Response of physical properties to tillage and residue management on two soils in a cool temperate environment. Soil and Tillage Research, 85; 143-153.

Bescansa, P., Imaz, J.M., Virto, I., Enrique, A. and Hoogmood, W.B. 2006. Soil water retention as affected by tillage and residue management in semi-arid Spain. Soil and Tillage Research, 87; 19-27.

Bhattacharyya, R. Prakash,V., Kundu, S. and Gupta, H.S. 2006. Effect of tillage and crop rotations on pore size distribution and soil hydraulic conductivity in sandy clay loam soil of indian Himalayas. Soil and Tillage Research, 86 (2); 129-140.

Boone, F.R. 1988. Weather and other environmental factors influencing crop responses to tillage and traffic. Soil and Tillage Research, 1 (1); 283-324.

Bouyoucos, G.J. 1951. A recalibration of the hydrometer for making mechanical analysis of soil. Agronomy Journal, 43; 435-438.

Bremner, S. M. 1982. Total nitrogen. In: Methods of Soil Analysis Part II, A.L. Page (ed.), pp. 595-624. Madison, WI, ASA-SSSA.

Bronik, C.J. and Lal, R. 2005. Manuring and rotation effects on soil organic carbon concentration for different aggregate size fractions on two soil in northeastern Ohio ,USA. Soil and Tillage Research, 81; 239-252.

Bybordi, M. 1990. Soil Physics. Fourth Edition, Publication of Tehran University. Pub. No: 1672, (Persian).

Cassel, D.K. and Nielsen, D.R. 1986. Field capacity and available water capacity. In: Methods of Soil Analysis, A. Klute (ed.), Part I, pp: 901-926. ASA and SSSA Agronomy Monograph No 9, Madison, WI, USA.

Chenu, C., Le Bissonnais, Y. and Arrouays, D. 2000. Organic matter influence on clay wettability and soil aggregate stability. Soil Sci. Soc. Am.J., 64, 1479-1486.

Davies, D. B., Aagle, D. J. and Finney, J. B. 1999. Soil Management. Publication of Gilan University, No: 631/4 Rasht, Iran. (Translated by Akefh. M.,and Bageri I.)

De vita, P., Paolo, E.Di., Fecondo, G., Fanzo, N, Di. and Pisante, M. 2007. No-tillage and conventional tillage effects on durum wheat yield, grain quality and soil moisture content in southern Italy. Soil and Tillage Research, 92:69-78. 
420

421

422

423

424

425

426

427

428

429

430

431

432

433

434

435

436

437

438

439

440

441

442

443

444

445

446

447

448

449

450

Diaz-Zorita, M. and Grosso, G.A. 2000. Effect of soil texture, organic carbon and water retention on compactability of soils from Argentinean pampas. Soil and Tillage Research, 54:121-126.

Doran, J.W. and Zeiss, M.R. 2000. Soil health and sustainability: managing the biotic component of soil quality. Applied Soil Ecology, 15; 3-11.

Filho, C., Lourenço, A., Guimaraes, M. de F. and Fonsecac, I.C.B. 2002. Aggregate stability under different soil management systems in a red latosol in the state of Parana, Brazil, Soil and Tillage Research, 65; 45-51.

Follet, R.F. 2001. Soil management concepts and carbon sequestration in cropland soils. Soil and Tillage Research, 61; 77-92.

Gajri, P. R., Gill, V.K.S. Chaudhary, M.R. and Singh, R. 1997. Irrigation of sunflower in relation to tillage and mulching. Agricultural Water Management, 34; 149-160.

Gajri, P. R., Arora, V.K. and Perihar, S.S. 2002. Tillage for Sustainable Cropping. Food Product Press, New York.

Germann, P.F., Edwards, W.M. and Owens, L.D. 1984. Profiles of bromide and increased soil moisture after infiltration into soils with macro pores. Soil Sci. Soc. America Journal, 48; 237-244.

Glanz, J.T. 1995. Saving Our Soil: Solutions for Sustaining Earth's Vital Resource. Johnson Books, Boulder, CO, USA.

Godwin, R. J. 1990. Agriculture engineering in development: Tillage for crop production in areas of low rainfall. FAO, Rome.

Ghuman, B.P. and Sur, H.S. 2001. Tillage and residue management effects on soil properties and yields of rainfed maize and wheat in a sub-humid subtropical climate. Soil and Tillage Research, 58; 1-10.

Gumus, I. and Seker, C. 2015. Influence of humic acid applications on modules of rapture, aggregate stability, electrical conductivity, carbon and nitrogen content of a crusting problem soil. Solid Earth, 6; 1231-1236.

Hajabbasi, M.A. and Hemmat, A. 2000. Tillage impacts on aggregate stability and crop productivity in a clay-loam soil in central Iran. Soil and Tillage Research, 56; 205212.

Hillel, D. 1980. Fundamentals of Soil Physics. Academic Press, London. 
451

452

453

454

455

456

457

458

459

460

461

462

463

464

465

466

467

468

469

470

471

472

473

474

475

476

477

478

479

480

481

482

Holland J. M. 2004. The environmental consequences of adopting conservation tillage in Europe: reviewing the evidence Agriculture, Ecosystems and Environment, 103, 125.

Husnjak, S., Filipoviç, D. and Kosutic, S. 2002. Influence of different tillage systems on soil physical properties and crop yield. Rostlinna Vyroba, 48(6); 249-254.

Jackson, M. 1958. Soil Chemical Analysis. P. 495, Prentice-Hall, Inc. Englewood Cliffs, New Jersey. USA.

Jaiyeoba, I. A. 2003. Changes in soil properties due to continuous cultivation in Nigerian semi-arid Savannah. Soil and Tillage Research, 70; 91-98.

Kahlon, M.S., Lal, R. and Varughese, M. A. 2013. Twenty two years of tillage and mulching impacts on physical characteristics and carbon sequestration in Central Ohio. Soil and Tillage Research, 126; 151-158.

Kasper, M., Buchan G.D., Mentler, A. and Blum, W.E.H. 2009. Influence of soil tillage systems on aggregate stability and the distribution of $\mathrm{C}$ and $\mathrm{N}$ in different aggregate fraction. Soil and Tillage Research, 105; 192-199.

Kemper, W. D. and Rosenau, R. C. 1986. Aggregate stability and size distribution. In: Methods of Soil Analysis, A. Klute (ed.), Part I, pp: 425-442. ASA and SSSA Agronomy Monograph No 9, Madison, WI, USA.

Klute, A. and Dirksen, C. 1986. Hydraulic Conductivity and Diffusivity: Laboratory Methods. In: Methods of Soil Analysis, A. Klute (ed.), Part I, pp: 687-732. ASA and SSSA Agronomy Monograph No 9, Madison, WI, USA.

Laegreid M., Bockman, O.C. and Kaarstad, O. 1999. Agriculture, fertilizers, and the environment. NorskHydro ASA.CABI Publishing, Porsgrunn, Norway.

Lal, R. 1991. Tillage and agricultural sustainability. Soil and Tillage Research, 20; 133-140.

Lal, R. 1999. Soil compaction and tillage effects on soil physical properties of a mollic Ochraqualf in northwest Ohio. Journal of Sustainable Agriculture, 14; 53-65.

Lampurlanes, J., Angas, P. and Cantero-Martinez, C. 2001. Root growth, soil water content and yield of barley under different tillage systems on two soils in semi-arid conditions. Field Crop Research, 69 (1); 27-40.

Logsdon, S.D., Allmaras, R.R., WU, L., Swan, J.B. and Randall, G.W. 1990. Macroporosity and its relation to saturated hydraulic conductivity under different tillage practices. Soil Sci. Soc. America Journal, 54 (4); 1096-1101. 
483

484

485

486

487

488

489

490

491

492

493

494

495

496

497

498

499

500

501

502

503

504

505

506

507

508

509

510

511

512

513

Mahboubi, A.A., Lal, R. and Faussey, N.R. 1993. Twenty-eight years of tillage effects on two soils in Ohio. Soil Sci. Soc. Am. J., 57; 506-512. Soil Sci. Soc. America Journal, 57 (2); 506-512.

Marinari, S., Masciandar, G., Ceccanti, B. and Grego, S., 2000. Influence of organic and mineral fertilizers on soil biological and physical properties. Bioresource Technology, 72, 9-17.

Martens, D.A. 2000. Management and crop residue influence soil aggregate stability. J. Environ. Qual. 29; 723-725.

McVay, K.A. 2006. Soil Physical Conditions in Conservation Tillage Systems. Kansas State Univ.-Research and Extensions. In .www. agecon. Oktate. Edu/ 1sct/laranza/mcvay/so1lphys.doc.

Meek, B.D., Rechel, E.R., Carter, L.M., DeTar, W.R and Urie, A.L. 1992. Infiltration rate of a sandy loam soil: Effects of traffic, tillage and plant roots. Soil Sci. Soc. America Journal, 56; 908-913.

Melero, S. Bellido, R.J.L., Bellido, L.L., Romero, V.M., Moreno, F. and Murillo, J.M. 2011. Long-term effect of tillage, rotation and nitrogen fertilizer on soil quality in a Mediterranean vertisol. Soil and Tillage Research, 114; 97-107.

Mosaddeghi, M.R., Mahboubi, A.A. and Safadoust, A. 2008. Short-term effects of tillage and manure on some soil physical properties and maize root growth in a sandy loam soil in western Iran. Soil and Tillage Research, 104 (1); 173-179.

Nelson, R.E. 1982. Carbonate and gypsum. In: Methods of Soil Analysis (A.L. Miller, R.H. Miller and D.R. Keeney eds.), ASA, Madison, WI, pp:149-157.

Nyamangara, J., Piha, M.I. and Kirchmann, H. 1999. İnteractions of aerobically decomposed cattle manure and nitrogen fertilizer applied to soil. Nutr. Cycl. Agroecosys., 54; 183-188.

Olsen, S.R., Cole, C.V., Watanabe, F.S. and Dean, L.A. 1954. Estimation of Available Phosphorous in Soils by Extraction with Sodium Bicarbonate. USDA Circular 9398, 1-19.

Osunbitan, J.A., Oyedele, D.J. and Adekalu, K.O. 2005. Tillage effects on bulk density, hydraulic conductivity and strength of a loamy sand soil in southwestern Nigeria. Soil and Tillage Research, 82; 57-64. 
Oussible, M. and Crookston, R.K. 1987. Effect of subsoiling a compacted clay loafil \$oil and growth, yield and yield components of wheat. Agronomy Journal, 19; 8821886.

516

517

518

519

520

521

522

523

524

525

526

527

528

529

530

531

532

533

534

535

536

537

538

539

540

541

542

543

544

545

Özpınar, S. ve Çay, A. 2005. Effects of minimum and conventional tillage system on soil properties and yield of winter wheat (Triticum aestivum L.) in clay-loam in the Çanakkale Region, Turkish Journal of Agriculture and Forestry, 29 (1); 9-18.

Pierce, C. and Burpee, G. 1995. Zone tillage effects on soil properties and yield and quality of potatoes. Soil and Tillage Research, 35; 135-146.

Romano, N., Hopmans, J. W. and Dane, J. H. 2002. Suction Table.In: Methods of Soil Analysis (Dane, J. H., Topp, E. C. eds.), Part 4: Physical Methods. SSSA Book Ser. 5, SSSA, Madison, WI, USA, pp. 692-698.

Roseberg, R.J. and Mc Coy, E.L. 1992. Tillage and traffic changes in macro porosity and macro pore continuity: an ability assessment. Soil Sci.Soc.Am. J., 56; 1261-1267.

Shaver,T., Peterson,G., Ahuja, L., Westfall, D., Sherrod, L. and Dunn, G. 2002. Surface soil properties after twelve years of dryland no-till management. Soil Sci. Soc. Am. J., 66; 1296-1303.

Shipitalo, M.J. and Protz, R. 1987. Comparison of morphology and porosity of a soil under conventional and zero tillage. Canadian Journal of Soil Science, 67; 445-456.

Singh, B. and Malhi, S.S. 2006. Response of soil physical properties to tillage and residue management on two soils in a cool temperate environment. Soil and Tillage Research, 85; 143-153.

Soil Survey Division Staff, 1993. Soil Survey Manual. USDA, Handbook No:18, Washington D.C.

Soil Survey Staff. 2006. Soil Taxonomy: A basic system of soil classification for making and interpreting soil surveys. $2^{\text {nd }}$ edition USDA NRCS Agr. Handbook No. 436. Washington, DC.

Sojka, R.E. and Upchurch, D.R. 1999. Reservations regarding the soil quality concept. Soil Sci. Soc. Am. J., 63 (5); 1039-1054.

Srivastava, J. and Meyer, E. 1998. Is conservation tillage a viable option in the CIS? Draft paper, World Bank, Washington.

Strudly, M.W., Green,T.R. and Ascough, J.C. 2008. Tillage effects on soil hydraulic properties in space and time: State of the science. Soil and Tillage Research, 99;448. 
Solid Earth Discuss., doi:10.5194/se-2017-13, 2017

Manuscript under review for journal Solid Earth

Discussion started: 1 March 2017

(c) Author(s) 2017. CC-BY 3.0 License.

546 Su, Z., Zhang, J., Wenliang, W., Cai, D., Lv, J., Jiang, G., Huang, J., Gao, J., Hartmann, R. and Gabriels, D. 2007. Effects of conservation tillage practices on winter wheat water-use efficiency and crop yield on the Loess Plateue, China. Agricultural water management, 87 (3); 307-314.

Traore, O., Groleau-Renaud, V., Plantureux, S., Tubeleh, A. and Boeuf-Tremblay, V. 2000. Effect of root mucilage and modelled root exudates on soil structure. Eur. J. Soil Sci. 51; 575-581.

U.S. Salinity Lab. Staff, 1954. Diagnosis and Improvement of Saline and Alkali Soils. Agric, Handbook No: 60, P 160, Washington, D.C.

Vepraskas, M.J. 1988. Bulk density values diagnostic of restricted root growth in coarse textured soils. Soil Sci. Soc. Am. J., 52; 1117-1121.

Whalen, J. K. and Chang, C. 2002. Macroaggregate characteristics in cultivated soils after 25 annual manure applications. Soil Sci. Soc. Am J., 66; 1637-1647.

$\mathrm{Xu}, \mathrm{D}$. and Mermoud, A. 2001. Topsoil properties as affected by tillage practices in North China. Soil and Tillage Research, 60(1-2); 11-19.

561 Zhang, X.Y., Cruse, R.M., Sui, Y.Y. and Jhao, Z. 2006. Soil compaction induced by small tractor traffic in northeast China. Soil Sci. Soc. Am. J., 70; 613-619. 